\title{
The Tufts and Bushes of Meaning or \\ Merleau-Ponty and the \\ Second Language Learner
}

\author{
Michael B. Smith \\ Berry College
}

Des significations en touffe, des buissons de sens propres et de sens figurés.'

Merleau-Ponty's long reflection on the being of language, as it appears here and there in practically all of his works in one form or another, has found but faint echo elsewhere. There have been attempts to bring him into the fold of structuralism, generative grammar, ${ }^{2}$ or semiotics, but for reasons too complex to explore here, MerleauPonty's writings on language can scarcely be thought of as "contributions" to the field of linguistics or semiotics. They are largely concerned with the elaboration of a metaphysics and an epistemology in which language is viewed more as a mode of being and of understanding than an object of scientific investigation.

As a phenomenological philosopher, Merleau-Ponty is interested in describing what language is, in terms of its meaning. His chief concern is not the meanings of sentences within language, nor the "significance" of language for humans, but the meaning of the personin-language and language-in-the-person as two aspects of a unitary mode of being. My purpose here is to isolate certain aspects of Merleau-Ponty's phenomenological description of language that are insightful and possibly relevant to the practical study of foreign languages. I do not intend to make specific recommendations to the enterprise of foreign language teaching on the basis of these brief pages. Nevertheless, I hope that they may prompt reflection on some aspects of second language acquisition that are rarely discussed. The consideration of these aspects arises from the nature of language as apprehended by Merleau-Ponty. If he is right about what language is, then there may be grounds for altering quite radically the way in which we understand the significance and process of second language learning.

It is important to state from the outset that Merleau-Ponty's reflection concerns language far more frequently that it does individual languages. By language I mean not only language in general, but also the initiating and in a sense conclusive experience we all have in learning how to speak as children. Our mother tongue will doubtless forever constitute for us "language," just as for Proust the water lilies of the Vivonne were more "real" than "the flowers they show me 
today" (1954, p. 184). Our first encounter with language opens up a dimension of being, a field of "things to say," and an effability of unspecified idioms.

But the extent to which reflection about language is applicable to a second or foreign language is not immediately obvious. A first phase of thought on this question would no doubt point out important differences. Without analyzing these differences in detail, I suggest that they may be classified into two categories: (a) those that are derived from the cognitive and affective level of maturity of the subject at the time the language was learned, and (b) those that stem from the very order in which the languages are learned; for example, inherent primacy and secondariness of the experience. With respect to the first category of differences we must recognize that the learner of a "first" language is, by the nature of the human condition, a child. The set of aptitudes he or she brings to the task of language learning differ from those of the second language learner, whom we may assume to be usually considerably older. The strengths of the older language learner (skill in manipulating abstract or grammatical notions, and a basic understanding of how symbolic systems operate) are quite distinct from those of the child (a more diffuse, or less structured perceptiveness, mimesis, interest in "playing" with the possibilities of his or her phonic apparatus). The second category of difference is not determined by the age of the learner, but rather by the fact of prior exposure to and assimilation of a system of verbal symbolism or lack thereof. It appears likely that the way in which a mind already at home in the world of verbal symbolism goes about assimilating a second, alternative system is somewhat different from the way in which a mind without such resources seizes upon language. For example, if I learn that the English word "sleet" means grêle in French, or more precisely that "sleet" means more or less the same thing to me that grêle means to a French person, I may eventually succeed in transferring the experiential content of the English word to the French one in such a way that the end result is quite similar. I may use and react to the French word similarly to the way I do to the English word. But the way in which I assimilated the new term was nonetheless different from the way I learned "sleet."

It is the initial linguistic experience with the first language that is of particular interest to Merleau-Ponty. He describes vividly in the following passage the way in which we are to imagine that the world meaning and word meaning of the term "sleet" comes into being experientially.

One day I"caught on" to the word "sleet," much as one imitates a gesture, not, that is, by analysing it and performing an articulatory or phonetic action corresponding to each part of the word as heard, but by hearing it as a single modulation of the world of sound, and because this acoustic entity presents itself as "something to pronounce" in virtue of the all-embracing correspondence existing between my perceptual 
potentialities and my motor ones, which are elements of my indivisible and open existence. The word has never been inspected, analysed, known and constituted, but caught and taken up by a power of speech and, in the last analysis, by a motor power given to me along with the first experience I have of my body and its perceptual and practical fields. As for the meaning of the word, I learn it as I learn to use a tool, by seeing it used in the context of a certain situation. The world's meaning is not compounded of a certain number of physical characteristics belonging to the object; it is first and foremost the aspect taken on by the object in human experience, for example my wonder in the face of these hard, then friable, then melting pellets falling ready-made from the sky. (1962, p. 403)

Once we have recognized the importance of these differences between first versus second language learners, it is important to remember that there are similarities in the two projects, based on the nature of languages and the goal to be attained.

All languages are per se "first languages." There may well be traits common to those special versions of languages that are used as "second" languages. For example, secondary systems may be frequently more abstract, less deeply anchored in the psycho-semantic affectivity of the speaker, and so on. And in a sense there may be said to exist a "first-year French" idiom, with its vocabulary based on word-count frequency, the omission of obscenities, and a propensity for regular verbs. The term "interlangue" has been proposed (see Note 4) as a designation for the version of a language in flux as it exists within the second language learner, of which more will be said later. But even these special idioms or incomplete versions of languages possess, as we shall see, the basic characteristics of language as described by Merleau-Ponty.

Furthermore, beyond these differences, my goal as a second language learner is to achieve mastery of the second language closely resembling my mastery of my native tongue. The degree of success I have achieved as a second language learner can be measured by comparison with the spontaneity, fluency, and ease of the native speaker or of my own expression as native speaker of my mother tongue. Though analysis and reflection clearly play a more important role in second than in first language learning, the goals of easy and nuanced communication and personal expressivity are common to both.

Until now, foreign language methodologies have received their impetus mainly from linguistics, an outgrowth of philology; in the future they may well find renewal via a psycho-linguistics based on a phenomenology of language. It is to the task of rendering more explicit certain recurrent traits in Merleau-Ponty's phenomenological descriptions of language that I devote the following pages. 


\section{The We of Language}

The Cartesian ego is, as Marvell said of the grave, "a fine and private place" but "none I think do there embrace." That solipsistic prison without walls is not the setting in which Merleau-Ponty places language; rather he locates it in the field stretching between the twin polarities of "I" and "you." That dialogual space is the domain of the "we." As the chief institution of intersubjectivity, language provides the milieu in which "I" and "the others" can blend into a common world. ${ }^{3}$ It is as if, enveloped by language, the other becomes introjected into myself and I into the other. I am referring here to the commonality prerequisite of discourse, which may of course as easily lead to discord as harmony in its realization.

When I speak or understand, I experience that presence of others in myself or of myself in others. ... To the extent that what I say has meaning, I am a different "other" for myself when I am speaking and to the extent that $I$ understand, I no longer know who is speaking and who is listening. (Merleau-Ponty, 1964, p. 97)

As Hans-Georg Gadamer insists in Man and Language (1976, p. 65), speaking does not belong in the sphere of the "I" but in the sphere of the "we." The "we" of language is not a plurality of "I"s, as the false symmetry of grammar would lead one to believe, but rather a blending of the "I" and "you" into an indistinctness rendering verbal distinction possible.

A discussion is not an exchange or a confrontation of ideas, as if each formed his own, showed them to the others, looked at theirs, and went back to correct them on the basis of his own.... Someone speaks, and the others immediately become no more than certain divergencies in relation to his words, and he himself specifies his divergencies in relation to them. Whether he speaks loudly or barely whispers, each speaks with all that he is, with his "ideas," but also with his obsessions, his secret history which the others suddenly lay bare by formulating them as ideas.... No one thinks anymore, everyone speaks, all live and gesticulate within Being. (Merleau-Ponty, 1968, p. 119, translation slightly modified)

This is an accurate description of the experience of an animated discussion. This is the being of language, and difficult though it may be in the typical classroom setting to imagine how such being can be fostered, Merleau-Ponty's description of it enables us at least to formulate the problem accurately and uncompromisingly. Speaking is not just talking.

By the phrase "No one thinks anymore, everyone speaks," we are to understand, not that speech has become "thoughtless," but that thought and speech are two modalities, mute and uttered, of the same "phenomenon." But Merleau-Ponty would doubtless have rejected this formulation of the relationship between thought and speech, since (a) a phenomenon is precisely what shows itself, and 
therefore it is speech that is the phenomenon (and perhaps thought as well), not some other entity of which speech would be the manifestation, and (b) he is more concerned with redescribing the actual experience of speech-thought than with explaining it on the basis of abstract postulates. Rather, in order to express the Husserlian Ueberschreitung, the Ineinander of intertwined phenomena, he has recourse to a literary device only cautiously employed by philosophers: the metaphor. Yet, so pervasive and consistent are MerleauPonty's vegetation metaphors that one has the impression that they are being used not as literary embellishment but as intuitable emblems essential to his expostion of the rerum natura.

\section{The Leafy Metaphors of the "Entrelacs"}

These metaphors, which borrow their vocabulary from growing plants, show the relationship between language and thought, experience and idea, listener and speaker. The following description of the relationship between thought and language moves toward a verdurous metaphor in which the two luxuriantly burgeon into one another.

All thought comes from spoken words and returns to them; every spoken word is born in thoughts and ends up in them. Between men and within each man there is an incredible growth of spoken words, whose nerve is "thoughts." There is not thought and language; upon examination each of the two orders splits in two and sends a branch out into the other.

(Merleau-Ponty, 1964, pp. 17, 18)

In The Visible and the Invisible we find a very similar use of the leaf-structure metaphor, with this difference that the "nerve," "vein," or "nervure" of the leaf (French la nervure) is here used to represent the idea, which gives experience its inner structure; whereas in the above example it represented the thought within words.

As the nervure bears the leaf from within, from the depths of its flesh, ideas are the texture of experience; its style, first mute, then uttered. (Merleau-Ponty, 1968, p. 199, translation slightly modified)

The appropriateness of the image here is, first, the interiority of structure of both experience and language. Structure is not viewed as something to be deduced from an ipso facto disposition of parts, but rather as an internal and active principle that carries and sustains from within. Secondly, there is growth: not accretion from without, but development from within. The French term used by Merleau-Ponty in this passage for "uttered" is proféré, or proffered, which has the etymological suggestion of carried forward, and is almost as appropriate to trees putting out leaves as to people uttering words. Despite the descriptive vividness of these metaphors, one may be justified in asking whether the recognition of the 
interrelatedness of phenomena is per se a sufficient reason for a philosopher not to attempt to unwind the confusion of lived experience for the purpose of understanding it better. Whatever our own view of this may be, one of the working notes from The Visible and the Invisible gives us an insight into Merleau-Ponty's own view of this question.

In Ideen II, Husserl, "to disentangle" "to unravel" what is entangled. The idea of chiasm and Ineinander is on the contrary the idea that every analysis that disentangles renders unintelligible. (Merleau-Ponty, 1968, p. 268 , translation slightly modified)

This telegraphic statement from his posthumously published work is doubtless to be understood in the context of his much earlier one (1945) from the preface to Phenomenology of Perception: "The real has to be described, not constructed or formed."

Before ending this very brief account of Merleau-Ponty's description of language I would like to mention one last metaphor in which the borrowed figure is not from the vegetable but from the animal world.

\section{The Animal of Words.}

In the phrase "animal or words" we are not to understand animal as the human animal, a being who is characterized by speech. The expression, which Merleau-Ponty borrows from Paul Valéry, is meant to describe language itself as a living organism made up of words. Speaking of the sedimented acts of creativity that we take up in the form of a linguistic tradition, a language, Merleau-Ponty writes:

We have this acquisition as we have arms and legs. We make use of it without a thought, just as without thinking we "find" our arms and legs; and Valery was right to call this speaking power in which expression premeditates itself the "animal of words." (1964, p. 18)

The first element to be noticed is that this verbal body, as it were, is composed of a set of acquired abilities or powers. The term "acquired" may appear inappropriate here. Do we acquire language as one might a house or a car? Surely we entertain a much closer relation to language than that. Furthermore, we speak of language as a verbal body, yet we do not normally think of our bodies as acquired items. The background of this terminological anomaly is enlightening.

At the conclusion of The Structure of Behavior, Merleau-Ponty develops a relativized, dialectical concept of "body."

The body in general is an ensemble of paths already traced, of powers already constituted; the body is the acquired dialectical soil upon which a higher "formation" is accomplished, and the soul is the meaning which is then established. (1963, p. 210) 
Hence, the body is not an external entity that has been acquired, but is defined as "that which has been acquired" and may be thought of as the form of a function or the accretion of a repeated activity. Clearly this sense of acquisition, in which the acquired becomes the core of further action, is quite remote from the external relation obtaining between owner and owned. The soul is cast as the avantgarde of being, and assimilated to parole parlante (speaking word, speech), while body represents, on the linguistic level, parole parlée (language).

The verbal body may be thought of as a habitus possessed of the capacity for a certain degree of spontaneity; just as our physical body, though to some degree a servant to the mind, is also capable of reacting spontaneously, particularly in situations of danger or surprise. To make the point that our "verbal body" also has this ability, Merleau-Ponty quotes Marivaux.

"I do not dream of calling you coquettish. Those are things that are said before one dreams of saying them." Said by whom? Said to whom? Not by a mind to a mind, but by a being who has body and language to a being who has body and language, each drawing the other by invisible threads like those that hold the marionettes-making the other speak, making him think and become what he is but would never have been by himself. Thus it occurs that things are said and are thought by a Speaking and a Thinking that we do not have but that have us. (1964, p. 79, translation slightly modified)

We have language like we have our physical body. We have it, but it has us as well, since there are times when we would like to escape from its hold on us but cannot (viz., illness, imprisonment etc.). We have language, but only on the condition and to the degree that it has us. We cannot chose not to understand what is said to us in a language we understand, nor to be unaffected by what is said to or about us in it. It is this bilateral possession that Merleau-Ponty has expressed in the formula "La prise est prise," the taking is taken, or the grasp has been grasped; and that most accurately describes the mutual implication of the relationship that obtains between language and ourselves.

One of the recent terms that has emerged in the literature on second language acquisition is interlangue, or interlanguage. ${ }^{4}$ An interlanguage is an unfinished state of the language under study as it is used by the student: a nucleus of fledgling powers of comprehension and expression consisting of certain structures basic to the language, phrases embodying phonetic and semantic material. Such a concept appears to me to be very much in keeping with Merleau-Ponty's insight about language as a verbal body; both emphasize the organic nature of this being, and its quality of "mineness," of personal acquisition, as well as its potential for openness to otherness. 


\section{Conclusion}

Merleau-Ponty's description of language speaks more directly to the learning of language than to the teaching of it. This is quite to be expected, since, first, languages are to a great extent self-teaching, which of course they must be if they are to pass on from generation to generation, so that an understanding of the nature of language would already reveal some of the traits that make languages "contagious"; and secondly, teaching is itself a secondary or derived function, the practice of which can be based on nothing other than an understanding and furtherance of learning.

The consciousness one has of the process to which one lends oneself as a language learner may prove to be of more importance than has previously been supposed. Research into the lived experience of bilinguals will continue to furnish data relevant to language learning. The view of the student as a third-person entity to be manipulated for his or her own good by the teacher is being increasingly called into question. In its place is emerging a legitimization of the learner's self-perception and growing interest in the mysterious grafting of a new linguistic system onto an existing manifold of expressive powers. The narration of this essentially personal experience constitutes a rich field of research, in which language acquisition and introspective linguistic awareness are closely interrelated.

Traditionally, it has not been thought essential to engage the learner of a second language in a reflective way in the meaning of the overall language learning project. The learner was rather more of a "subject" (often in both senses of the term), upon whom various methods were "tried." Merleau-Ponty's way of approaching language (and the prereflective roots of perception and expression in general) is through a highly reflective "return." Translated to the level of praxis in the domain of language learning, such an approach would indicate that it is vain to try to repeat our first language learning experience. The learning of a second language is in fact the only way in which we can return, and this time reflectively, to the experience of language learning. Consciously now, equipped with a fully developed system of expression with which to comprehend and express the experience, we return to language. We can return to it because we can leave it, stand outside it, and hear as if for the first time that baroque assemblage of sounds, witness the secret burgeoning of meaning out of form. Merleau-Ponty's descriptions of language and thought establish a level, a way of speaking, or a frame of discourse in which the "subjective" experience of those who would encounter a new language (and language anew) may find a way of expressing that experience. One of the merits of his work from this particular point of view is to have reopened for fresh perception and description an area of human experience that periodically seems to become covered over with positive knowledge, or facts, the authority of which is derived from the prestige of that bastion of last recourse, reality. 
Language, doubling back upon itself, will no doubt continue to attempt to ask and answer the question of its own Being, a Being which appeared to Merleau-Ponty to exist in the interrogative mode.

\section{Notes}

1. "Significations in tufts, thickets of proper meanings and figurative meanings." (Merleau-Ponty, 1968, p. 130) The French text is in Le visible et l'invisible, Gallimard, p. 172.

2. Compare for example, Luce Fontaine and De Visscher. (1974). Phénomène ou Structure? Essai sur le language chez Merleau-Ponty. Saint-Louis, Bruxelles: Publ. des Fac. Univ.

3. It is not entirely accurate to speak here of a "blending" of the "I" and the "other." I strongly suspect that what Merleau-Ponty is referring to as the undifferentiated milieu of the "we" which provides the backdrop of speech is the transposition onto linguistic territory of the concepts of syncretic sociability, introjection, and transitivism as used by Piaget, Scheler, Stern and Wallon. See Merleau-Ponty. (1964). The primacy of perception (pp. 141 et seq.). Evanston: Northwestern University Press. Also see Merleau-Ponty. (1973). Consciousness and the acquisition of Language (p. 45 et passim). Evanston: Northwestern University Press. If this is correct, the "I" and the "you" are derived entities arising from an ambiant, non-egocentric consciousness that still provides language with its horizonal milieu.

4. Other terms designating the student's transitional, operative version of the language include "idiosyncratic dialects," "français approché," "systèmes approximatifs" and "système intermédiaire." Cf. Frauenfelder, U., Porquier, R. (1980) "Enseignants et apprenants face à l'erreur." In Le Francais dans le Monde, 154, 29-36.

\section{References}

Gadamer, H.G. (1976). Philosophical hermeneutics. Berkeley: University of California Press.

Merleau-Ponty, M. (1962). Phenomenology of perception. London: Routledge \& Kegan Paul.

Merleau-Ponty, M. (1963). The structure of behavior. Boston: Beacon Press.

Merleau-Ponty, M. (1964). Signs. Evanston: Northwestern University Press.

Merleau-Ponty, M. (1968). The visible and the invisible. Evanston: Northwestern University Press.

Proust, M. (1954). A la recherche du temps perdu (Vol. I). Ed. Pléiade, Paris: Gallimard. 